\title{
Correction to: Transmission of H7N9 influenza virus in mice by different infective routes
}

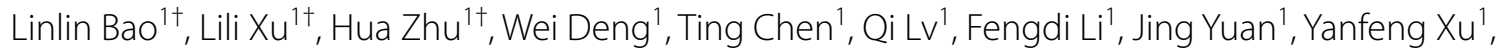
Lan Huang ${ }^{1}$, Yanhong Li ${ }^{1}$, Jiangning Liu' ${ }^{1}$, Yanfeng Yao ${ }^{1}$, Pin Yu' ${ }^{1}$, Honglin Chen ${ }^{2}$ and Chuan Qin ${ }^{\text {* }}$

\section{Correction to: Virology Journal 2014, 11:185} https://doi.org/10.1186/1743-422X-11-185

Following publication of the original article [1], the authors realised that in Fig. 2a, the immunohistochemical result of the kidney of the negative control mouse was unfortunately misplaced with lung tissue. The correct photo has now been replaced as shown below. The authors would like to apologise for this mistake and are very sorry for the inconvenience caused.

Authors would like to confirm that this correction does not impact the conclusions of the study. 


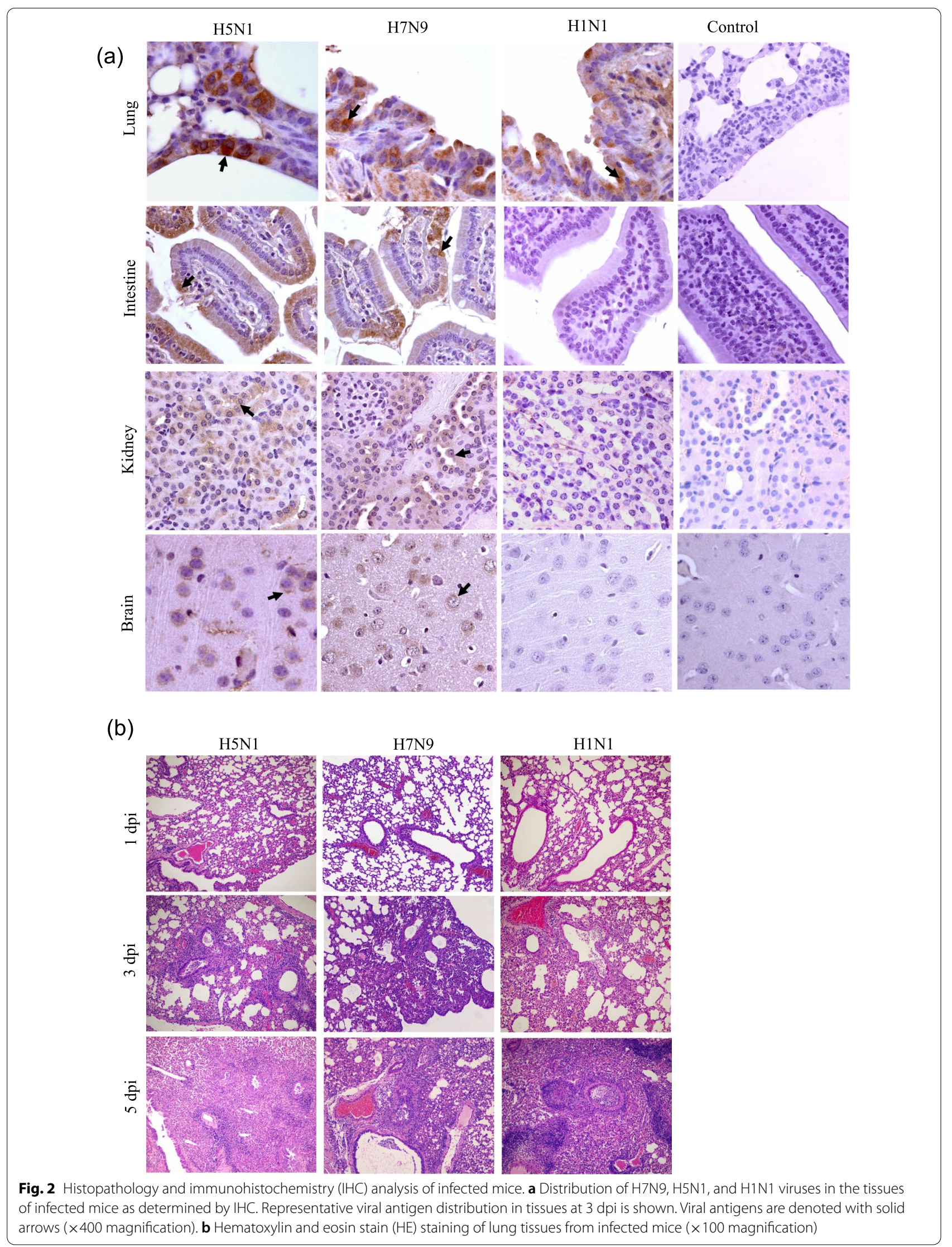




\section{Author details}

'Institute of Laboratory Animal Sciences, Chinese Academy of Medical

Sciences (CAMS) \& Comparative Medicine Center, Peking Union Medical

Collage (PUMC); Key Laboratory of Human Disease Comparative Medicine,

Ministry of Health, No. 5 Pan Jia Yuan Nan Li, Chaoyang District, Beijing 100021,

China. ${ }^{2}$ Department of Microbiology and the Research Center of Infection and Immunology, State Key Laboratory for Emerging Infectious Diseases, The

University of Hong Kong, 21 Sassoon Road, Pokfulam, Hong Kong, SAR, China.

Published online: 06 July 2021

\section{Reference}

1. Bao L, et al. Transmission of H7N9 influenza virus in mice by different infective routes. Virol J. 2014;11:185. http://www.virologyj.com/content/ $11 / 1 / 185$

\section{Publisher's Note}

Springer Nature remains neutral with regard to jurisdictional claims in published maps and institutional affiliations.
Ready to submit your research? Choose BMC and benefit from:

- fast, convenient online submission

- thorough peer review by experienced researchers in your field

- rapid publication on acceptance

- support for research data, including large and complex data types

- gold Open Access which fosters wider collaboration and increased citations

- maximum visibility for your research: over $100 \mathrm{M}$ website views per year

At BMC, research is always in progress.

Learn more biomedcentral.com/submissions 